\title{
In vivo Study of a Collagen Impregnated Polyester Arterial Prosthesis: the Arteknit Ra $\mathbf{K}^{\circledR}$ Graft
}

\author{
Peter Ondruš, Roman Alberty*, Jacques Lamarche**, Vincent Echavé***, Jacques Poisson*** \\ Department of Cardiac Surgery, F. D. Roosevelt Hospital, *Department of Biology, Faculty of Sciences, \\ Matthias Belivs University, Banská Bystrica, Slovak Republic, **Department of Pathology, Sherbrooke University Hospital, \\ ***Department of Surgery, Sherbrooke University Medical Center, Sherbrooke, Québec, Canada
}

Ondruš P, Alberty R*, Lamarche J**, Echavé V***, Poisson J*** (Department of Cardiac Surgery, F. D. Roosevelt Hospital, *Department of Biology, Faculty of Sciences, Matthias Belivs University, Banská Bystrica, Slovak Republic, **Department of Pathology, Sherbrooke University Hospital, ***Department of Surgery, Sherbrooke University Medical Center, Sherbrooke, Québec, Canada). In vivo Study of a Collagen Impregnated Polyester Arterial Prosthesis: the Arteknit Ra $\mathbf{K}^{\circledR}$ Graft. Cor Vasa 2006;48(1):12-18

Purpose: We have previously reported that a transient increase in intracellular $\mathrm{Ca}^{2+}$ concentrations in endothelial-like cells may reflect the endothelization process on the Arteknit $\mathrm{Ra} \mathrm{K}^{\circledast}$ polyester arterial prosthesis implanted in the aorta of mongrel dogs (Physiol Res 51; 217-20:2002). In this study, we further examine early arterial graft healing, i. e. patency, morphology, endothelization and thromboresistance, after short implantation periods in these dogs.

Methods: We implanted 12 Arteknit Ra $\mathrm{K}^{\circledast}$ prostheses in the aorta of mongrel dogs for scheduled periods ranging from 48 hours to 6 months. The explanted graft specimens were subjected to histological examination and scanning electron microscopy, analyzed for platelet and fibrinogen uptake as well as prostacyclin $\left(\mathrm{PGI}_{2}\right)$ and thromboxane $\mathrm{A}_{2}\left(\mathrm{TXA}_{2}\right)$ concentrations.

Results: At the time of sacrifice, all grafts were structurally intact and 11 of them showed afair dimensional stability. After 48 hours, an acute moderate inflammatory response was observed, later replaced by chronic inflammatory reaction with foreign-body giant cells still present at 6 months. After 1 month, patches of endothelial-like cells were formed in both anastomotic regions. The mid-portion of the graft was infiltrated by an organizing thrombotic matrix with sparsely distributed endothelial-like cells for the whole period of the experiment. After 3 months, the luminal collagen coating was bioeroded and collagen degradation did not interfere with the healing process. Thick external capsules were observed in the thorax at 3 and 6 months post implant. Within 1 and 6 months, the fibrinogen and platelet uptake was generally low and PGI ${ }_{2}$ : TXA ratios determined in whole segments of the graft were higher than 1 .

Conclusions: This Arteknit Ra $\mathrm{K}^{\oplus}$ polyester prosthesis has shown suitable dimensional stability and moderate biocompatibility and satisfactory healing performance in terms of tissue and inflammatory reactions.

Key words: Arterial prosthesis - Polyester fibers - Thoraco-abdominal bypass graft - Histologic evaluation - Thromboresistance

Ondruš P, Alberty R*, Lamarche $\mathrm{J}^{* *}$, Echavé $\mathrm{V}^{* * *}$, Poisson $\mathrm{J}^{* * *}$ (Kardiochirurgické oddelenie, Nemocnica F. D. Roosevelta, *Katedra biológie, Fakulta prírodných vied Univerzity M. Bela, Banská Bystrica, Slovenská republika, **Department of Pathology, Sherbrooke University Hospital, ***Department of Surgery, Sherbrooke University Medical Center, Sherbrooke, Québec, Kanada). In vivo štúdia kolagénom impregnovanej polyesterovej tepennej protézy: štep Arteknit Ra ${ }^{\circledR}$. Cor Vasa 2006;48(1):12-18.

Ciel: Už pred časom sme uviedli, že prechodné zvýšenie vnútrobunkovej koncentrácie $\mathrm{Ca}^{2+} \mathrm{v}$ bunkách podobných endotelu môže odrážat' priebeh endotelizácie na polyesterovej tepennej protéze typu Arteknit Ra $\mathrm{K}^{\circledast}$, implantovanej do aorty nečistokrvných psov (Physiol Res 2002;51:217-20). V tejto štúdii sme u týchto psov po krátkodobej implantácii hodnotili včasné vhojenie tepenného štepu, t. j. jeho priechodnost', morfológiu, endotelizáciu a tromborezistenciu.

Metódy: Do aorty nečistokrvných psov sme na vopred určené obdobie v rozmedzi 48 hodín až 6 mesiacov implantovali 12 protéz typu Arteknit Ra $\mathrm{K}^{\circledast}$. Vzorky vyňatého štepu boli vyšetrené histologicky a skenovacou elektrónovou mikroskopiou, analyzované na vychytávanie krvných doštičiek a fibrinogénu, a zároveň aj na koncentráciu prostacyklínu $\left(\mathrm{PGI}_{2}\right)$ a tromboxánu $\mathrm{A}_{2}\left(\mathrm{TXA}_{2}\right)$.

Výsledky: V čase utratenia mali všetky štepy neporušenú štruktúru a $11 \mathrm{z}$ nich vykazovalo vyhovujúcu rozmerovú stabilitu. Po 48 hodinách bola pozorovaná akútna, stredne závažná zápalová odpoved’, ktorú neskôr nahradila chronická zápalová reakcia s obrovskými bunkami okolo cudzieho telesa, ktoré boli prítomné aj po 6 mesiacoch. Po jednom mesiaci sa v obidvoch oblastiach anastomózy vytvorili pláty endotelu-podobných buniek. Stredná čast’ štepu bola po celý čas trvania pokusu infiltrovaná organizovanou trombotickou matrix s ojedinele roztrúsenými endotelu-podobnými bunkami. Po troch mesiacoch došlo k biologickej erózii luminálneho povlaku kolagénu a jeho rozklad neprekážal procesu hojenia. Tri až šest’ mesiacov po implantácii boli v hrudníku pozorované na vonkajšom povrchu štepu zhrubnuté kapsule. V priebehu jedného až šiestich mesiacov bolo vychytávanie krvných doštičiek a fibrinogénu celkove nízke a pomerové indexy $\mathrm{PGI}_{2}$ : TXA ${ }_{2}$ stanovené vo všetkých častiach štepu boli vyššie ako 1 .

Závery: Polyesterová protéza typu Arteknit Ra $\mathrm{K}^{\oplus}$ vykázala vyhovujúcu rozmerovú stabilitu, stredne vysokú biokompatibilitu a uspokojivé vhojenie v zmysle tkanivových a zápalových reakcií.

Klúčové slová: Tepenná protéza - Polyesterové vlákna - Thorako-abdominálny štep pre bypass - Histologické vyšetrenie Tromborezistencia

Address: doc. RNDr. Roman Alberty, CSc., Katedra biológie, Fakulta prírodných vied, Univerzita M. Bela, Tajovského 40, 97401 Banská Bystrica, Slovenská republika, e-mail: alberty@fpv.umb.sk 


\section{INTRODUCTION}

Polyester vascular prostheses are widely accepted as a substitute for reconstruction of medium- and largediameter arteries. To date, various concepts have been developed to improve their materials, mechanical properties, healing performance and, hence, their patency rate. The Arteknit $\mathrm{Ra} \mathrm{K}^{\circledR}$ prosthesis represents a new generation of the original vascular devices manufactured in Eastern Europe (Knitting Research Institute, Brno, Czech Republic). It is a warp-knitted textile arterial prosthesis made of multifilament yarns, impregnated with bovine collagen. A few years ago, Guidoin et al. evaluated this type of the prosthesis for clinical use and found poor long-term dimensional stability and an excessive inflammatory reaction during the first month in vivo, which delayed the healing performance. Moreover, they recommended to improve some technological procedures during the production of warp-knitted prostheses and reevaluated them subsequently.(1)

In this context, we sought to perform an evaluation of the patency, healing sequence and surface thrombogenicity of the Arteknit $\mathrm{Ra} \mathrm{K}^{\circledast}$ prosthesis, implanted as a thoraco-abdominal bypass in mongrel dogs. All these evaluation procedures were performed at the Medical Center of Sherbrooke University (Sherbrooke, Québec, Canada).

\section{MATERIALS AND METHODS}

\section{Graft materials}

The Arteknit Ra $\mathrm{K}^{\circledR}$ prosthesis is a non-biodegradable, warp-knitted three-dimensional prosthesis constructed of texturized polyester multifilament yarns. To diminish impermeability to blood, bovine collagen was impregnated into a porous graft wall (30-40 mg of collagen/1 g prosthesis). A $2.0 \%(\mathrm{v} / \mathrm{v})$ solution of melamine-formaldehyde resin was used for the crosslinking of collagen fibers. Undesirable residua of the formaldehyde resin are completely removed by washing of the prosthesis. It has a mean water permeability of $5 \mathrm{ml} / \mathrm{min} / \mathrm{cm}^{2}$ at $16 \mathrm{kPa}$ and shows no visible signs of dilatation; the longitudinal tension is at least $70 \mathrm{~N} / \mathrm{cm}$. The biological and microbial properties meet the European standards EN ISO 10993 for the implantation of biomaterials in the human body. In this study, a straight and crimped configuration of the $\mathrm{Ra} \mathrm{K}^{\circledast}$ prostheses was used; all implants were $25 \mathrm{~cm}$ long and $8 \mathrm{~mm}$ in diameter.

\section{In vivo implantation}

Twelve adult mongrel dogs, weighing between 16 and $24 \mathrm{~kg}$, were selected and cared for according to the Canadian Council on Animal Care regulations. The in vivo evaluation of the $\mathrm{Ra} \mathrm{K}^{\circledR}$ device involved implanting the prosthesis as a canine thoraco-abdominal bypass for scheduled periods of 48 hours, 1 and 2 weeks, and 1, 3, and 6 months as described in detail previously. ${ }^{(2,3)}$ Prior to surgery, the dogs fasted for 24 hours, to be subsequently anesthetized with $32 \mathrm{mg} / \mathrm{kg}$ of intravenous sodium pentobarbital (Somnotol ${ }^{\oplus}$; MTC Pharmaceutical Ltd., Hamilton, Ontario, Canada), intubated, and mechanically ventilated. The thoracic aorta was isolated via left thora- cotomy through the eighth intercostal space. The abdominal aorta was mobilized from the renal arteries to the aortic trifurcation through a midline lower abdominal incision. After surgery, the dogs were returned to their cages and fed an unrestricted standard diet.

\section{Angiography}

Angiograms were taken prior to harvesting the grafts implanted for 6 months. Conray 60 (Mallinckrodt Canada Inc., Montreal, Québec, Canada) was used as the contrast medium.

\section{Graft harvesting}

At the end of the scheduled implantation time, each dog was returned to the operating room and anesthetized as mentioned above. Blood samples were drawn for hematological analysis and platelet labeling. Thirty minutes before sacrifice, labeled platelets and fibrinogen were injected into the right femoral vein. Thereafter, heparin $(0.5 \mathrm{mg} / \mathrm{kg})$ was administered intravenously in order to minimize post mortem thrombotic deposits over the graft surface. The dog was exsanguinated via the right iliac artery. The graft was removed by a thoracophrenolaparotomy, opened longitudinally, carefully rinsed and photographed to assess the macroscopic findings. Specimens in the proximal, medial and distal regions were cut for determination of platelet and fibrinogen uptake, prostaglandin secretion and pathological investigation.

\section{Histologic and scanning electron microscopy}

Pathologic analysis was carried out on the proximal and distal anastomotic regions as well as the midportion of each graft. Each specimen was divided into two sections for analyses. The first half was in a $2 \%$ isotonic buffered glutaraldehyde solution, rinsed in distilled water, and postfixed in osmium tetroxide. Drying was completed by immersion in a series of aqueous ethanol solutions of increasing concentrations, followed by critical point drying using liquid $\mathrm{CO}_{2}$ as the transfer medium. The specimen was then coated with gold palladium and examined in a Jeol JSM 35 CF scanning electron microscope (Soquelec, Montreal, Québec, Canada). The second portion was fixed in a $10 \%$ solution of formalin and, after embedding, 5-um sections were cut and stained with hematoxylineosin, Weigert and Masson's trichrome.

\section{Platelet and fibrinogen uptake studies}

Platelet and fibrinogen retained over graft surface were determined by means of an isotopic technique using indium ${ }^{111}$-labeled platelets and iodine ${ }^{125}$ -labeled fibrinogen. ${ }^{(4)}$ For platelet labeling, $20 \mathrm{ml}$ of autologous blood in sodium citrate was collected and centrifuged at 1,000 rpm for 8 minutes. Platelet-rich plasma was then incubated with $100 \mu \mathrm{Ci}$ of indi$\mathrm{um}^{111}$-oxinate for 15 minutes at room temperature. Two aliquots $(0.05 \mathrm{ml})$ of this labeled suspension were preserved as standards for total radioactive counts. The labeled platelets were then centrifuged at 2,500 rpm for 10 minutes. The platelet pellet was resuspended in $2.5 \mathrm{ml}$ of saline, and 2 aliquots $(0.05 \mathrm{ml})$ of the supernatant were preserved as second standard for determining the radioactive count remaining in the 


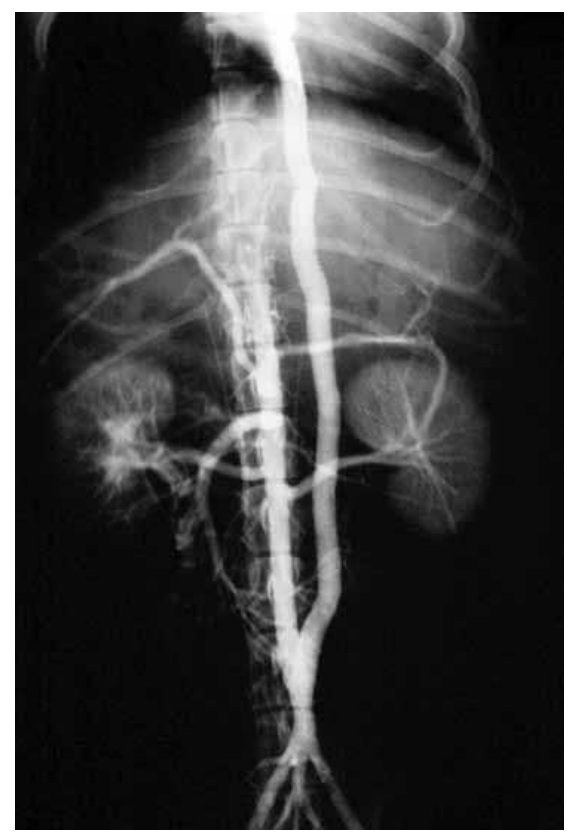

Figure 1

Angiogram of the polyester Arteknit $\mathrm{Ra} \mathrm{K}^{\circledast}$ prosthesis at 6 months post implant.

suspension. A commercial solution of labeled iodine ${ }^{125}$-fibrinogen (Amersham Canada, Oakville, Ontario, Canada) was dissolved in $1.1 \mathrm{ml}$ of distilled water. Two aliquots $(0.01 \mathrm{ml})$ were also preserved as standard. Thirty minutes before sacrifice, the labeled platelets and $10 \mu \mathrm{Ci}$ of the labeled fibrinogen were injected into the right femoral vein. Platelet and fibrin uptakes over the proximal, medial and distal regions of each prosthesis were determined with a two-channel gamma LKB Rack Gamma scintillation counter (Fisher, Montreal, Québec, Canada). Counts per minute obtained from each channel were translated into a percentage of labeled platelet and fibrin uptake on each region of the graft.

\section{Prostacyclin and thromboxane $A_{2}$ synthesis}

The stable hydration products of prostacyclin $\left(\mathrm{PGI}_{2}\right)$ and thromboxane $\mathrm{A}_{2}\left(\mathrm{TXA}_{2}\right)$, 6-keto PGFla and thromboxane $\mathrm{B}_{2}\left(\mathrm{TXA}_{2}\right)$, were measured by radioimmunoassay. ${ }^{(5)}$ Fresh $1 \mathrm{~cm}^{2}$ whole segments of the explanted prostheses were removed from the proximal, medial and distal regions, rinsed thoroughly in saline to remove any remaining blood and analyzed immediately for the amounts of $\mathrm{PGI}_{2}$ and $\mathrm{TXA}_{2}$ (RIA kits; New England Nuclear, Boston, USA). Segments of each region were tested in duplicate and the results expressed as the mean $\mathrm{PGI}_{2} / \mathrm{TXA}_{2}$ ratio for each of the three regions were also tested.

\section{RESULTS}

\section{In vivo evaluation in dogs}

The operations were performed successfully, and all 12 dogs survived in good condition until the scheduled date of sacrifice. The incision was resutured in two dogs. The two dogs scheduled for the six-month interval were investigated by angiography. The angiograms (Figure 1) showed that the grafts were straight, and no dilatations, wrinkles or stenoses were evidenced after six months of implantation.

\section{Patency and macroscopic observations}

All explanted grafts were patent at sacrifice. A summary of macroscopic healing characteristics of the Arteknit $\mathrm{Ra} \mathrm{K}^{\circledast}$ prostheses for each period of implantation is presented in Table I. All of the implanted grafts remained straight, with the exception of one in a dog scheduled for 3 months, where small angulation and dilatation $5 \mathrm{~cm}$ above the distal anastomosis were observed. A thicker thrombotic mass on the luminal surface $3 \mathrm{~cm}$ below the thoracic anastomosis was observed in one dog scheduled for 2 weeks, probably caused by clamping of the graft during implantation. External tissue adhesions were normal in the abdomen; however, those in the thorax became

Table I

Macroscopic analysis of explanted Arteknit Ra $\mathrm{K}^{\oplus}$ grafts

\begin{tabular}{|c|c|c|c|c|c|}
\hline Period & Graft shape & $\begin{array}{l}\text { Ext. tissue } \\
\text { adhesion }\end{array}$ & $\begin{array}{l}\text { External } \\
\text { capsule }\end{array}$ & $\begin{array}{l}\text { Internal } \\
\text { capsule }\end{array}$ & Flow surface \\
\hline 48 hours & Straight & None & None & None & $\begin{array}{l}\text { Pale, very few thrombi in } \\
\text { valleys of crimps }\end{array}$ \\
\hline 1 week & Straight & Normal in abdomen & $\begin{array}{l}\text { Thin and fragile } \\
\text { in abdomen, almost } \\
\text { none in thorax }\end{array}$ & None & $\begin{array}{l}\text { Pale, very few thrombi in } \\
\text { valleys of crimps }\end{array}$ \\
\hline 2 weeks & Straight & Normal in abdomen & $\begin{array}{l}\text { Thick and very } \\
\text { fragile in thorax } \\
\text { and abdomen }\end{array}$ & $\begin{array}{l}\text { None, thin in } \\
\text { peri-anastomotic } \\
\text { regions }\end{array}$ & $\begin{array}{l}\text { More red pale, few thrombi } \\
\text { in valleys of crimps }\end{array}$ \\
\hline 1 month & Straight & $\begin{array}{l}\text { Normal in abdomen } \\
\text { and thorax }\end{array}$ & $\begin{array}{l}\text { Thick and fragile } \\
\text { in thorax and } \\
\text { abdomen }\end{array}$ & $\begin{array}{l}\text { Thin in } \\
\text { peri-anastomotic } \\
\text { regions }\end{array}$ & $\begin{array}{l}\text { Red, smooth, organized } \\
\text { thrombi in valleys of crimps }\end{array}$ \\
\hline 3 months & $\begin{array}{l}\text { Straight, in } \\
1 \text { dog dilatation }\end{array}$ & $\begin{array}{l}\text { Normal in abdomen, } \\
\text { excessive in thorax }\end{array}$ & $\begin{array}{l}\text { Thick, hard in } \\
\text { thorax and } \\
\text { abdomen }\end{array}$ & $\begin{array}{l}\text { Thin on whole } \\
\text { graft }\end{array}$ & $\begin{array}{l}\text { White, smooth, glistening } \\
\text { with few organized thrombi } \\
\text { in valleys of crimps }\end{array}$ \\
\hline 6 months & Straight & $\begin{array}{l}\text { Normal in abdomen, } \\
\text { excessive in thorax }\end{array}$ & $\begin{array}{l}\text { Thick, firm, with } \\
\text { extensive fibrosis } \\
\text { in chest in one dog }\end{array}$ & $\begin{array}{l}\text { Thin on whole } \\
\text { graft }\end{array}$ & $\begin{array}{l}\text { White, less red, smooth, } \\
\text { glistening with few organized } \\
\text { thrombi in valleys of crimps, } \\
\text { small yellow deposits }\end{array}$ \\
\hline
\end{tabular}


extensive at 3 and 6 months post implant. Thin fragile external capsules began to form after one week, and progressed into firm, thick and fibrotic capsules within 6 months. In both perianastomotic regions, a thin internal capsule began to form within 2 weeks, later covering the whole graft. In 48-hour and oneweek implants, the luminal surfaces were pale while, at 2 weeks, they became completely red due to thrombotic matrix formation. Later, in 6-month implants, more than $50 \%$ of the luminal surface turned white mainly in both perianastomotic regions, while the mid-portion of the graft remained dark red (Figure 2). No bleeding or peripheral hematoma were visible on the outside of any of the grafts.

\section{Histological and scanning electron microscopic findings}

After 48 hours, a moderate acute inflammatory reaction with predominance of neutrophil polymorphonuclear leukocytes was observed between the polyester fibers of the graft. Within one month, this neutrophilic reaction gradually disappeared to be replaced by chronic inflammatory infiltrate composed predominantly of foreign-body giant cells still present after 6 months (Figure 3). A thrombotic matrix present on the luminal surface of the graft at 48 hours thickened in the valleys of the crimps after one week (Figure 4) and was still present in some portions of the graft even after

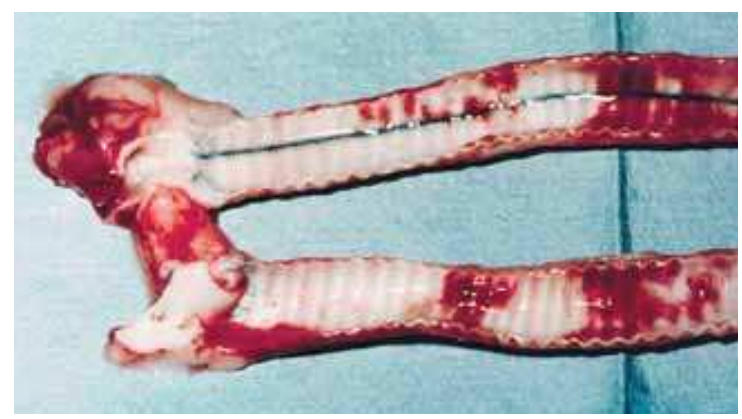

Figure 2 Macroscopic views of an explanted Arteknit Ra $\mathrm{K}^{\oplus}$ graft after implantation for six months. Smooth and whiteglistening entire flow surface near the distal anastomosis.

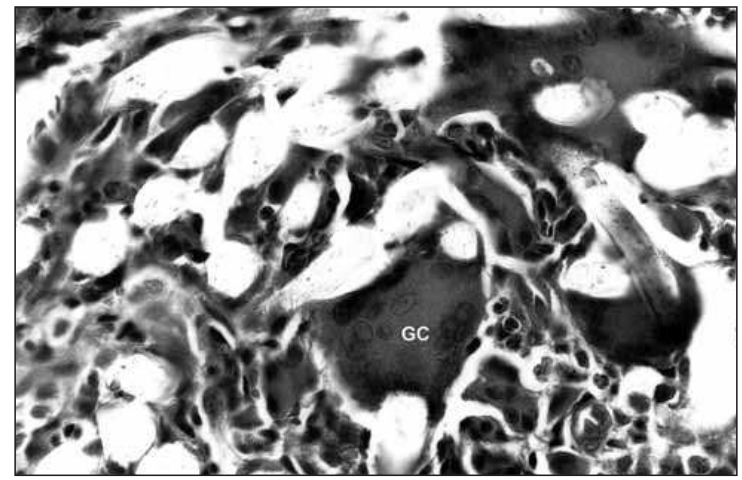

Figure 3 Light microscopic observation of the Arteknit Ra $\mathrm{K}^{\circledast}$ graft near the distal anastomosis after 1 month in vivo. An acute inflammatory reaction with numerous polymorphonuclear cells, lymphocytes and foreign-body giant cells (GC) in contact with polyester fibers (hematoxylin-eosin stain, $\times 480$ ).

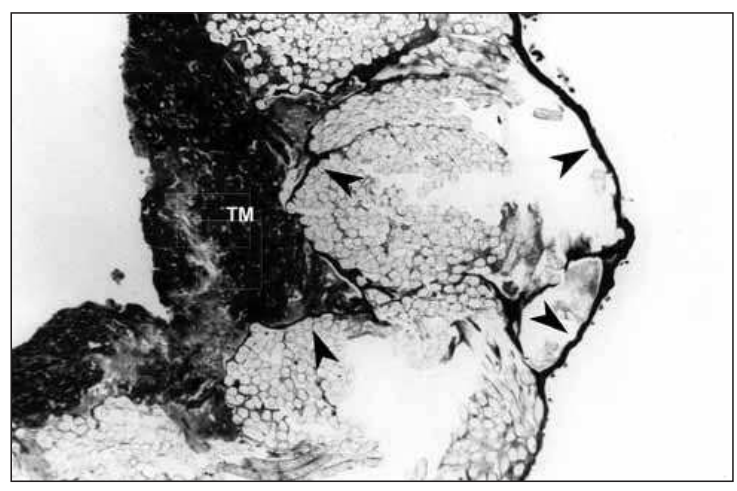

Figure 4 Light microscopic observation of the Arteknit Ra $\mathrm{K}^{\circledR}$ graft after 1 week in vivo. A thick thrombotic matrix (TM) in the mid-portion of the graft covers the luminal surface in the valleys of crimps. The collagen coating (arrows) is intact on the external and luminal surfaces (Masson stain, $\times 120$ ).

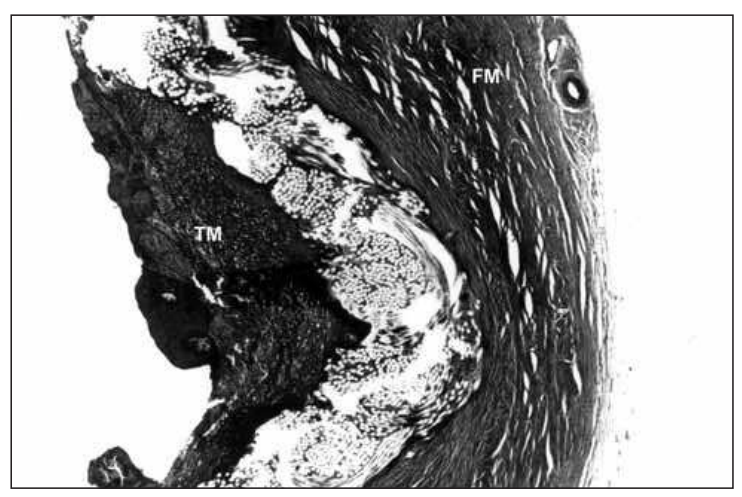

Figure 5 Light microscopic observation of the Arteknit Ra $\mathrm{K}^{\oplus}$ graft explanted after 6 months. A thick thrombotic matrix (TM) in the mid-portion of the graft covers the luminal surface in the valleys of crimps. Note the thick fibrous external matrix (FM) (Masson stain, × 120).

6 months (Figure 5). All along the graft, a fibrous capsule gradually formed on both surfaces (Figures 5 and 6). At 1 week, fibroblasti proliferation became apparent on the entire external surface of the graft (Figure 5) and after 2 weeks on its luminal surface along both anastomotic areas. The fibrous capsules were well established at 1 month and did not thicken significantly thereafter. Collagen coating degradation became evident on the luminal surface at 48 hours and on the external surface at 1 month. More than $50 \%$ of the internal collagen coating disappeared after 2 weeks. The coating was almost totally eroded on both surfaces of the graft after 3 months. After 1 week, endotheliallike cells were observed in both anastomotic regions, which became almost completely covered with these cells within 1 month (Figures 6 and 7). In the mid-portion of the graft, endothelial-like cells began to appear after 2 weeks and only islands of the cells were noted after 6 months (Figure 8).

\section{Platelet and fibrin uptake studies}

Platelet and fibrin accumulation on the luminal surfaces were calculated as a percentage of the counts per minutes $(\mathrm{cpm})$ on the graft compared to the total 


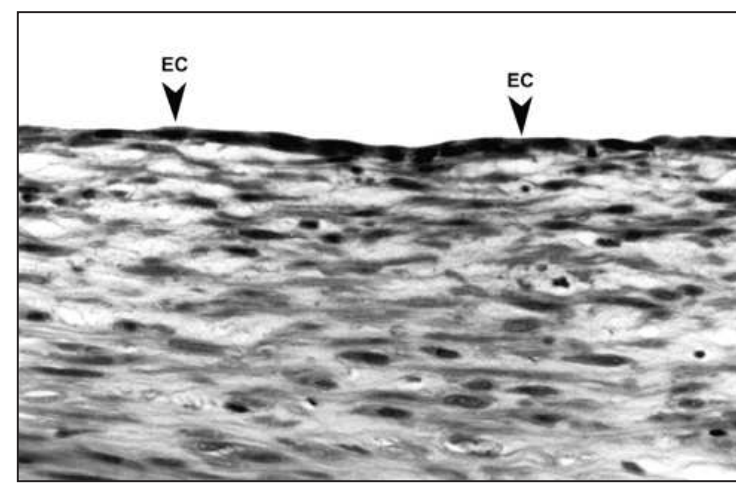

Figure 6 Light microscopic observation of the Arteknit Ra $\mathrm{K}^{\circledast}$ graft near the proximal anastomosis explanted after one month. The internal fibrous capsule is lined with endothelial-like cells (EC) (hematoxylin-eosin stain, $\times$ 480)

cpm injected. The maximum mean percentage of platelets present on the proximal, medial and distal regions was between 0.07 and $0.20 \%$ at 2 weeks, whereas the mean percentage of fibrin was mostly in the order of $10^{-2}-10^{-3}$ with a maximum in period as well as platelets (Figure 9).

\section{Ratio of $\mathbf{P G I}_{\mathbf{2}} / \mathbf{T X A}_{\mathbf{2}}$ secretion}

The $\mathrm{PGI}_{2}$ and $\mathrm{TXA}_{2}$ secretion rates for $\mathrm{Ra} \mathrm{K}^{\circledR}$ graft are shown as the means obtained from proximal, medial and distal regions for each period of implantation (Figure 10). The $\mathrm{PGI}_{2} / \mathrm{TXA}_{2}$ ratios were $<0.03$ after 48 hours of implantation. At 1 and 2 weeks, the ratios for this graft were unchanged, but increased after 1 month in situ with simultaneous endothelization of the luminal surface to 1.5-18.7 until 6 months.

\section{DISCUSSION}

Previously published protocols for polyester arterial prosthesis assessment were used to test the new series of $\mathrm{Ra} \mathrm{K}^{\circledR}$ warp-knitted vascular prostheses impregnated with collagen. ${ }^{(2,3)}$ The poor long-term dimensional stability in vivo described in a previous evaluation study, ${ }^{(1)}$ was not observed. Macroscopic and angiographic findings confirmed that up to 6 months after implantation, Arteknit Ra $\mathrm{K}^{\circledR}$ prostheses showed stable shape, and no obstructions or aneurysm formations were noticed.

As regards the healing process, however, this device produced an initial acute inflammatory response within the first two weeks after implantation, followed by a chronic cellular reaction with foreign-body giant cells persisting after 6 months. The pattern of cellular reactivity to a collagen-coated prosthesis has been neither presented nor discussed in detail in any previous studies evaluating polyester collagen vascular grafts. The type of inflammatory response has been specifically linked to the action of the agent used for collagen crosslinking. Formaldehyde collagen-coated grafts have been shown to induce an acute inflammatory reaction whereas glutaraldehyde cross-linking collagen coatings induce a chronic inflammatory response. ${ }^{(6)}$ The cellular reactivity to the graft might be related to one or several factors including collagen (presence of antibodies to type 1 bovine collagen), the cross-linking agent, poly-

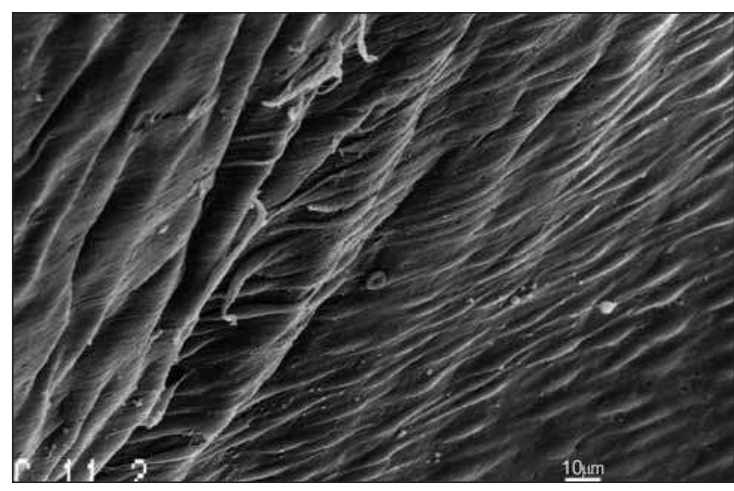

Figure 7 A scanning electron micrograph of the luminal surface of the Arteknit Ra $\mathrm{K}^{\circledast}$ graft near the proximal anastomosis at 1 month post-implant. The surface is entirely covered with a sheet of endothelial-like cells.

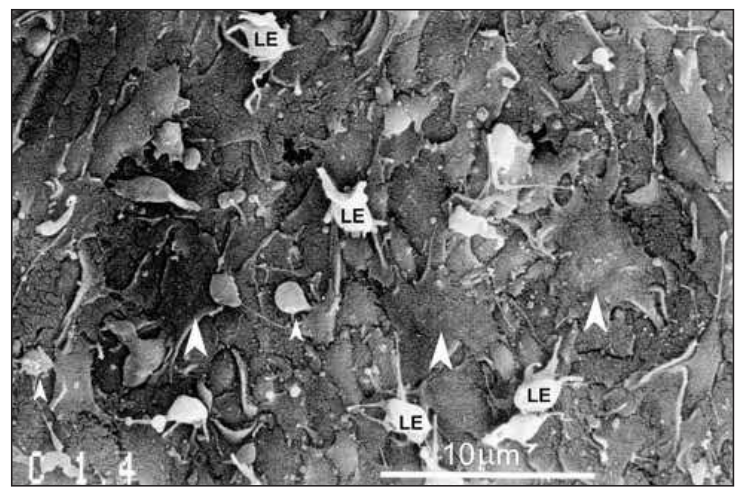

Figure 8 A scanning electron micrograph of the luminal surface of the Arteknit Ra $\mathrm{K}^{\circledR}$ graft at mid-portion at 6 months post-implant. A thrombotic matrix, sparsely distributed endothelial-like cells (large arrows), adhesive leukocytes (LE) and quiescent platelets (small arrows) are seen.

ester fibers and/or surface contaminants. In one study, the presence of surface contaminants was most likely responsible for the excessive inflammatory reaction by this prosthesis within 1 month in vivo, which resulted in delayed healing performance. ${ }^{(7)}$ In our opinion, the inflammatory response to the polyester graft is not specific regardless of the cross-linking agent, and is essentially a foreign-body reaction initiated by the presence of polyester fibers.

We have found that degradation of the collagen coating tends to be slower in the Ra $\mathrm{K}^{\circledR}$ graft than in the similarly coated polyester Hemashield ${ }^{\circledR}$ (Meadox Medicals, Oakland, NJ, USA) ${ }^{(8)}$ or Dialine $\mathrm{II}^{\circledR}$ (Cardial S. A., Saint-Étienne, France) prostheses. ${ }^{(9)}$ However, it is faster compared with the Tascon ${ }^{\circledR}$ prosthesis (Bionit, Billerica, MA, USA) coated with a glutaraldehyde cross-linked collagen;(7) such differences in degradation rates are common in in vivo studies, controlled primarily by a random hydrolytic reaction and by local enzymatic attack by macrophages and giant cells. It seems the inflammatory reaction and delayed degradation of the collagen coating of the $\mathrm{Ra} \mathrm{K}^{\circledast}$ prosthesis did not interfere with the healing process, which was quite similar to that observed with any polyester prostheses. 


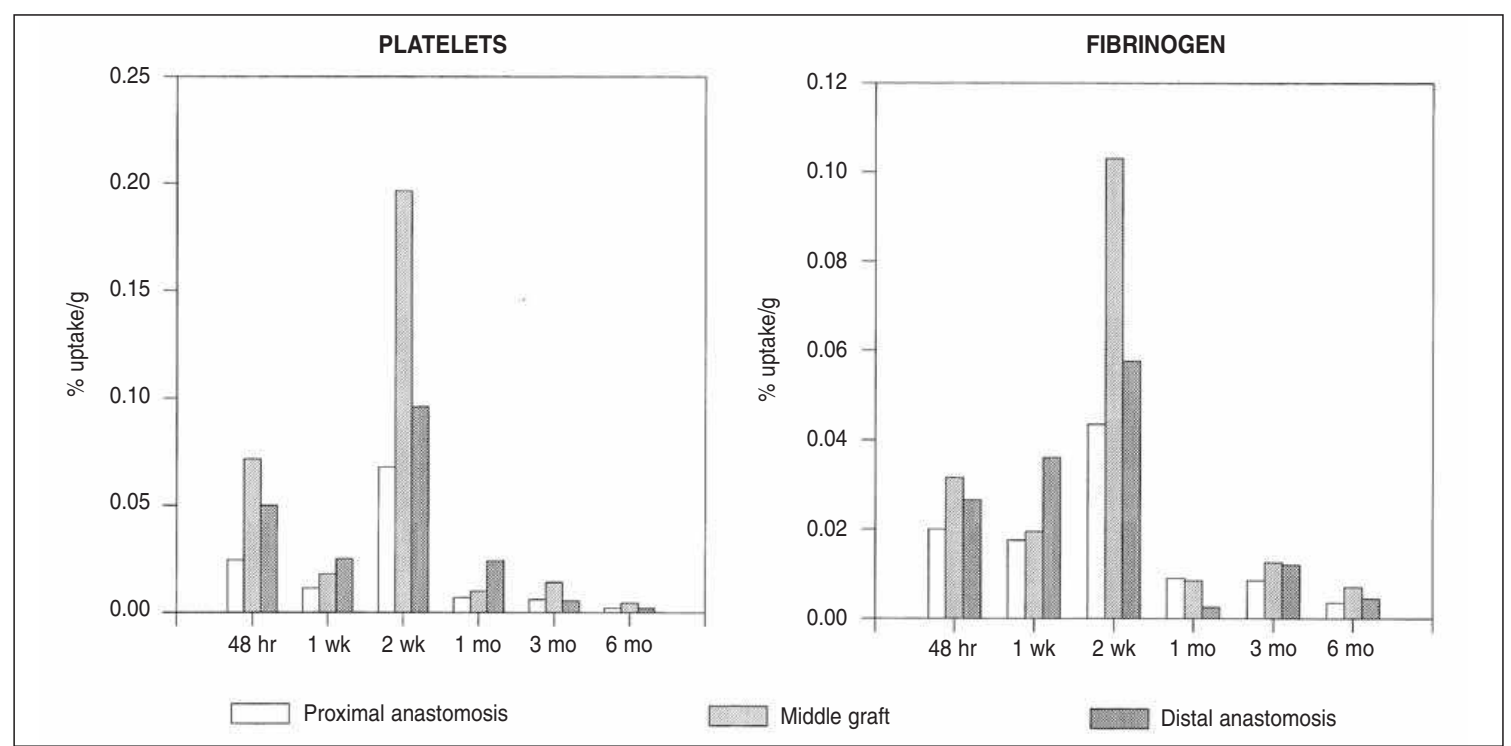

Figure 9 Quantification by radioassay of platelet and fibrinogen uptake in the Arteknit Ra $\mathrm{K}^{\circledR}$ graft during implantation.

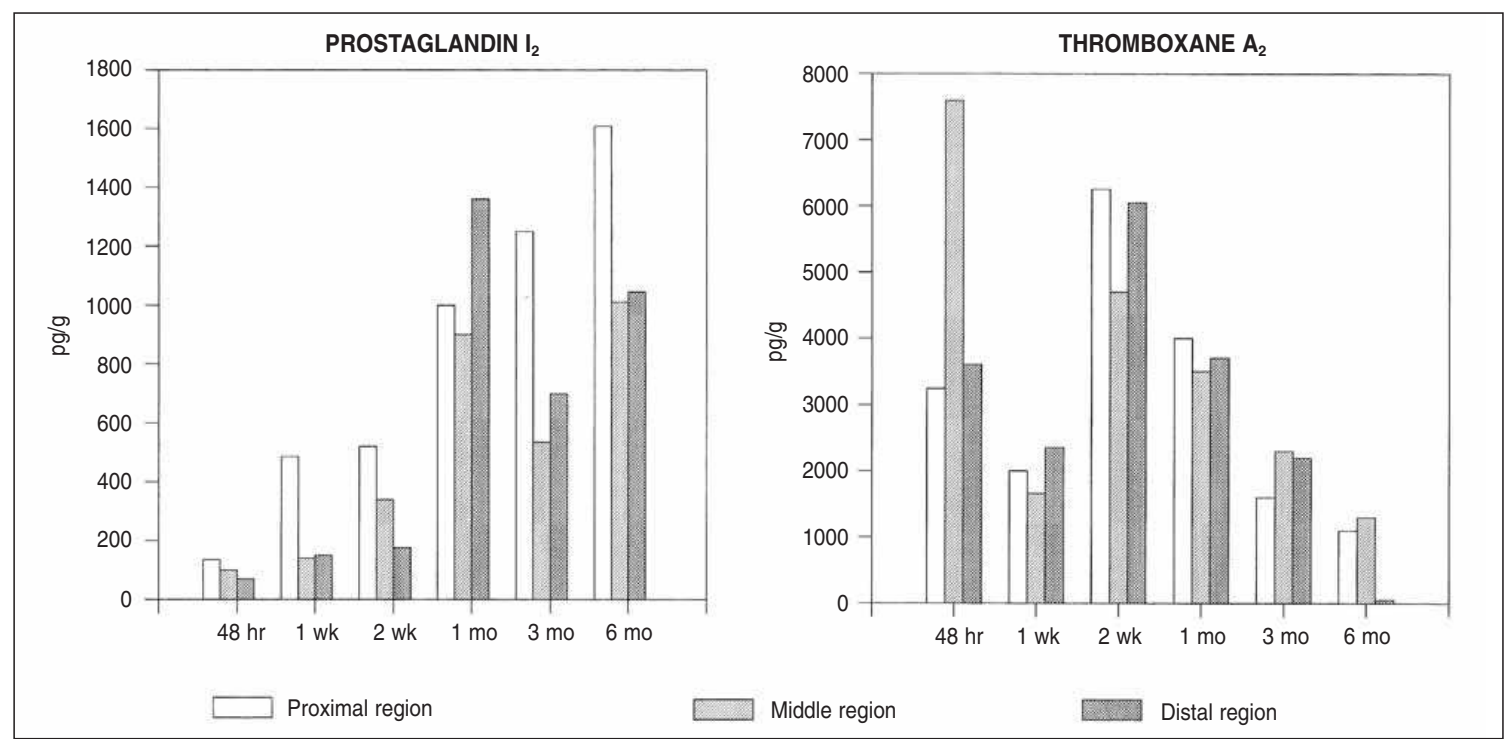

Figure 10 Quantification by radioimmunoassay of prostacyclin $\left(\mathrm{PGI}_{2}\right)$ and thromboxane $\mathrm{A}_{2}$ concentrations in the Arteknit Ra $\mathrm{K}^{\circledR}$ graft during implantation.

An important characteristic of the healing process is endothelization of the luminal graft surface. Endothelial-like cells lining the polyester graft surface are related to collagen erosion and may come from dividing of endothelial cells from the adjacent aorta, growing capillaries through the porous prosthesis, or circulating cells transformed to endothelial cells. ${ }^{(10)}$ Their baseline intracellular $\mathrm{Ca}^{2+}$ concentration during the healing period were reported by us elsewhere. ${ }^{(11)}$ The endothelization of the luminal surface of the polyester arterial prosthesis in the dog seems to be more complex compared to that found in human beings. ${ }^{(12,13)}$ At 1 month, a layer of endothelial-like cells completely covered the luminal surface at both anastomoses, whereas the medial luminal sur- face showed sparsely distributed endothelial-like cells for each period of this experiment.

Low thrombogenicity of flow surface is required in order to obtain long-term patency of the implanted prosthesis. Thromboxane $\mathrm{A}_{2}$, the predominant cyclooxygenase product in platelets, is a potential platelet agonist and a vasoconstrictor, whereas $\mathrm{PGI}_{2}$, the main product of the vascular endothelium, has opposite effects on platelet function and vascular tone. To date, the vessel system is considered the only organ system whereby $\mathrm{TXA}_{2}-\mathrm{PGI}_{2}$ play a relevant physiological and pathophysiological role creating a balance which, if perturbed, might predispose to either thrombosis or bleeding in vivo. ${ }^{(14)}$ Concerning the release of $\mathrm{TXA}_{2}$ or $\mathrm{PGI}_{2}$ from their synthesizing cells, the basic mechanism is well 
known. A rise in intracellular $\mathrm{Ca}^{2+}$ concentration is considered the initial event leading to phospholipase $\mathrm{A}_{2}$ activation and the liberation of arachidonic acid a precursor of $\mathrm{TXA}_{2}$ and $\mathrm{PGI}_{2}$ in the cyclooxygenase pathway. ${ }^{(15)}$ In our previous Arteknit Ra $\mathrm{K}^{\circledR}$ arterial prosthesis study, we described a transient increase in intracellular $\mathrm{Ca}^{2+}$ levels, probably as a result of shear stress and early inflammatory response to the arterial graft. ${ }^{(11)}$ Today, our data indicate that, at 2 weeks after implantation, the thrombogenicity of the luminal surface was significantly increased. Fibrinogen and platelet deposits were later promptly diminished. In all investigated grafts, $\mathrm{TXA}_{2}$ secretion decreased simultaneously with the increase in $\mathrm{PGI}_{2}$ secretion. These findings indicate the need for adjustment in local blood circulation whereby $\mathrm{TXA}_{2}$ released from stimulated platelets causes $\mathrm{PGI}_{2}$ formation in the endothelium that again inhibiting platelet activity. Moreover, the increase in $\mathrm{PGI}_{2}$ synthesis, shown at 1 month of the implant period, is typical for differentiating (endothelial) cells and smooth muscle cells in the case of a denuded vessel or damaged endothelium. ${ }^{(16)}$ Also, $\mathrm{TXA}_{2}$ secretions in the graft mid-portion at 6 months post implant were low indicating that the luminal surface was minimally thrombogenic although covered by a thrombotic matrix lacking neo-endothelial cells.

However, the study has several limitations: (1) We could not use all aspects of histological examination including the immunocytochemical staining of markers typical of or specific for endothelial cells, specific macrophage antigens or verified vascular smooth muscle cells lining the luminal surface of the arterial prosthesis. We felt confident, however, in the considerable experience in the area of vascular histology by the researcher from the laboratory of Sherbrook University (J. Lamarche). (2) We could not directly compare either the other commercially available vascular devices or to test an alternative approach in prosthesis handling before surgery (e.g., preclotting or short-term cultivation with autologous endothelial cells obtained from the recipient). (3) Finally, the investigation of $\mathrm{TXA}_{2}-\mathrm{PGI}_{2}$ couple regulation can be incomplete if not involving other regulators such as cytokines, growth factors, or additional eicosanoids and lipid mediators.

Despite these conditions, we think that the results presented in this study are of value for basic and applied research in the field of arterial device design. Moreover, the results may be helpful in decisionmaking concerning the selection of arterial prostheses in human medicine.

\section{CONCLUSION}

The collagen-impregnated Arteknit Ra $\mathrm{K}^{\circledast}$ arterial prosthesis has been found to be effective in preventing blood loss at the time of implantation while not significantly altering its in vivo shape stability. The Ra $\mathrm{K}^{\circledR}$ graft showed a slower rate of bioresorption of cross-linked collagen; however, its biocompatibility, healing behavior and antithrombogenic properties were comparable to the other polyester arterial prostheses investigated previously.

Acknowledgements: We greatly appreciate the help of Drs. R. Guidoin and Y. Marois, Biomaterials Insti- tute, Québec, Canada, with the establishment of the project and reviewing the manuscript. The authors also wish to thank to Dr. B. Lefébvre, Nuclear Medicine Department, Medical School, Sherbrooke University, for radioassay analysis. The technical assistance P. Magny and D. Martel from the Service of Electron Microscopy of Medical School, Sherbrooke University, Québec, Canada, is acknowledged.

\section{REFERENCES}

1. Gudoin R, King M, Marois Y, et al. Polyester arterial prostheses. Recent developments from the Czech Republic and Poland. ASAIO J 1997;43:69-83.

2. Goeau-Brissoniere O, Guidoin R, Marois M et al. Thoraco-abdominal bypass as a method of evaluating vascular grafts in the dog. Biomat Med Dev Art Org 1981;9:195-212.

3. Chafké N, Marois Y, Guidoin R, et al. Biocompatibility and biofunctionality of a gelatin impregnated polyester arterial prosthesis. Polymer \& Polymer Composites 1993; $1: 229-51$.

4. McCune, Blades W. The variability of long blood vessel grafts. Ann Surg 1954;134:769-81.

5. Merhi Y, Guidoin R, Forest JC. Fate of polyester arterial prostheses implanted as thoraco-abdominal bypass in dogs. Haematology, pathology and biochemistry. Clin Invest Med 1988;11:403-16.

6. Guidoin R, Marceau D, Rao TJ, et al. In vitro and in vivo characterization of an impervious polyester arterial prosthesis: the Gelseal Triaxial graft. Biomaterials 1987; 8:433-41.

7. Guidoin R, Marceau D, Couture J, et al. Collagen coatings as biological sealants for textile arterial prostheses. Biomaterials 1994;10:156-65.

8. The Canadian Multicenter Hemashield Study Group. Immunologic response to collagen-impregnated vascular grafts. A randomized prospective study. J Vasc Surg 1990;12:741-6.

9. Marois Y, Guidoin R, Deng X, King MW, Martin L, Roy $\mathrm{R}$. The Dialine II graft: a new collagen-impregnated warp-knitted polyester arterial prosthesis. Ann Vasc Surg 1997;11:133-40.

10. Scott MS, Barth MG, Gaddy LR, Ahl ET jr. The role of circulating cells in the healing of vascular prostheses. J Vasc Surg 1994; 10:585-93.

11. Ondruš P, Alberty R, Pothier P, Echavé V, Poisson J, Bkaily G. Cytosolic free $\mathrm{Ca}^{2+}$ concentration in canine aortic endothelial cells lining the polyester arterial prosthesis. Physiol Res 2002;51:217-20.

12. Wu MH, Shi Q, Wechezak AR, Clwes AW, Gordon IL, Sauvage LR. Definitive proof of endothelization of a Dacron arterial prosthesis in a human being. J Vasc Surg 1995;21:862-7.

13. Shi $\mathrm{Q}$, Wu MH, Onuki Y, et al. Endothelium on the flow surface of human aortic Dacron vascular grafts. J Vasc Surg 1997;25:736-42.

14. Bunting S, Moncada S, Vane JR. The prostacyclin-thromboxane $\mathrm{A}_{2}$ balance: pathophysiological and therapeutic implications. Br Med Bull 1983;39:271-6.

15. Choi J, Hammer LW, Hester RL. Calcium-dependent synthesis of prostacyclin in ATP-stimulated venous endothelial cells. Hypertens 2002; 39:581-5.

16. Ullrich V, Zou M-H, Bachschmid M. New physiological and pathophysiological aspects on the thromboxane $\mathrm{A}_{2}$-prostacyclin regulatory system. Biochim Biophys Acta 2001;1532:1-14.

Received 20 June 2005

Revision accepted 30 September 2005 